Article

\title{
Morphometric Characterization of the Lidia Cattle Breed
}

\author{
Juan Manuel Lomillos ${ }^{1, *(D)}$ and Marta E. Alonso ${ }^{2}$ (D) \\ 1 Department of Animal Production and Health, Veterinary Public Health and Food Science and Technology, \\ Veterinary Faculty, Universidad Cardenal Herrera-CEU, CEU Universities, 46113 Valencia, Spain \\ 2 Animal Production Department, Veterinary Faculty, University of León, Campus de Vegazana, 24071 León, \\ Spain; marta.alonso@unileon.es \\ * Correspondence: juan.lomillos@uchceu.es; Tel.: +34-660-043-528
}

Received: 14 June 2020; Accepted: 10 July 2020; Published: 13 July 2020

check for updates

Simple Summary: The Lidia breed has great economic and social importance and is one of the most interesting breeds worldwide from a genetic point of view. The economic, social, and genetic impact has not been reflected in zootechnical studies carried out on it because the difficulty of handling and approaching of this type of animal makes measurement of live individuals almost impossible. For this reason, the first morphological characterization of Lidia breed was carried out using photogrammetry. This technology facilitates measurements of animals at a distance from 3-dimensional photographs. In the present work, 264 adult individuals (males and females) were studied to determine 20 morphological measurements, 5 zootechnical indexes, and individual phaneroptic information. The results show a considerable internal variability, sexual dimorphism, and the zoomometric differentiation of various genetic lines, thus improving value and complexity of this breed.

\begin{abstract}
Morphometric studies in Lidia cattle are scarce due to the challenges of handling and approaching this breed of cattle. For this reason, the first morphological characterization of the Lidia breed was carried out using photogrammetry. In the present work, 264 adult individuals (184 males and 80 females), belonging to 21 different herds, were studied. A total of 20 morphological measurements and five indexes were determined in every individual. There were many positive correlations between the measures, giving the model great morphostructural harmony. Considerable internal variability of the studied parameters was observed. This breed reflected significant sexually dimorphic features and internal morphological differences between the different genetic lines of the breed. Lidia cattle are small and mostly have a sub-concave profile (58.4\% males and 69.7\% females). The male proportionality indexes and the relative depth of the thorax indicated great muscular development of the anterior third and high thoracic capacity. The phaneroptic information describes a mostly black animal with black mucous and hooves and an outstanding development of the dewlaps and the tail in the males.
\end{abstract}

Keywords: Lidia cattle; zoometry; photogrammetry

\section{Introduction}

The Lidia cattle constitutes the most numerous autochthonous bovine breed of Spain, with 199,662 heads distributed among 917 farms, and second, in censuses, after the holstein-friesian breed [1]. The current economic and social transcendence of this livestock production is corroborated by the large number of bullfighting shows, both in our country, 19,219 shows in 2018 [2], and in the South of France, Portugal and in many regions of Latin America (Ecuador, Mexico, Colombia, Peru and Venezuela). 
The origin of this breed goes back to the Middle Ages. Feudal lords raised these animals for hunting and war training purposes. The first reported evidence of artificial selection for Lidia bulls point to the fifteenth and sixteenth centuries. The developing farms in different areas of the Iberian Peninsula were clearly orientated to their use in taurine celebrations [3].

The modern Lidia breed can be considered the result of continuous selective pressure for behavioral phenotypes. Since the beginning of the 18th century, farmers used behavioral tests to choose certain ethological characteristics. Desired behaviors included prolonged durations of contest-behaviors.

These sequences of behaviors included charging against objects, people or animals, considering the morphology of the animal as secondary. Breeders deemed these patterns of behavior "bravura", indicating bravery because instead of fleeing, the animal displays strength and fierceness while facing danger. Therefore, from the zootechnical point of view, it is a unique breed in the world that has a valuable morphology and genetic resource, the latter, widely studied [4-7]. However, the desired behaviors also make the modern Lidia animals challenging to study. Handling and restraining these cattle are very dangerous due to their surly disposition, which may have prevented the realization of traditional manual morphological studies. Nonetheless, morphological characterization is important for the conservation and biodiversity of cattle breeds [8]. By studying the phenotypes within a breed, it is possible to improve diversity and selection for adaptation to the environment and functionality $[9,10]$.

Visual methods provide a non-invasive mechanism to evaluate cattle but are currently limited because the work requires skilled observers, is very laborious, and precision requires a high sampling rate [11-16]. Researchers previously described morphology and phaneroptics of this breed; however, few studies focused on zoometrical measures in Lidia cattle [17-19]. In addition, previous research was focused on the biometry of the horns rather than all of the features [20-22].

Previous zoometric-tool sets included standard measuring sticks, non-elastic measuring tape, a compass, goniometers, and calipers, which [23] required handling and restraint. In addition, handling and restraint may cause distress. Very temperamental animals may need to be immobilized using cattle crushes or containment boxes and possibly tranquilized. These procedures increase the risk of injury for both the animal and humans involved. Over the last two decades, technology advanced to improve various image-analysis techniques. One of them, known as near object photogrammetry, allows for morphological measurements on dangerous and elusive animals, such as the Lidia cattle, without risk to the operator or stress to the animal $[24,25]$. The technique was previously used to study wild animals such as elephants [26], orcas [27], and Wedded seals [28] and was validated for pigs, horses, and dairy cows [29-31]. The objective of this work was to adapt the photogrammetric technology to the Lidia breed and carry out the first zoometric and morphological characterization of the breed.

\section{Materials and Methods}

The morphometry and phaneroptics data of 264 adult individuals (4-6 years) of Lidia cattle (184 males and 80 females), belonging to 21 herds, selected as representative herds in the purity of the 15 genetic lines (called "encastes") that are currently preserved of the breed: Miura, Pablo Romero, Veragua, Murube, Santa Coloma-Buendía, Santa Coloma-Graciliano, Gamero Cívico, Conde de la Corte, Atanasio-Lisardo, Domecq, Torrestrella, Núñez, Albaserrada, Vega-Villar and Navarra [6] were enrolled. Birth records provided by the farmer were used to determine the age of the animals, which correlated with their ear tag.

All farms were located throughout the entire national territory of Spain (from Navarra in the north to Andalusia in the south), all of them in a common ecosystem called "Dehesa" or Mediterranean forest, characterized by a wooded grassland (30-100 trees per ha), mainly dedicated to extensive livestock with a Mediterranean climate with significant summer drought $[1,11]$.

The equipment used (Figure 1) is an adaptation of the one described by Gaudioso et al. [32] that consists of a rigid and tubular structure supported in its central part by a vertical peg (Figure 1). Three cameras were attached to the structure using articulated supports. These supports allowed for adjusting the orientation of the cameras according to the size of the object to be measured and the 
average distance to which it is located. The lateral cameras were synchronized and remotely controlled by cable.

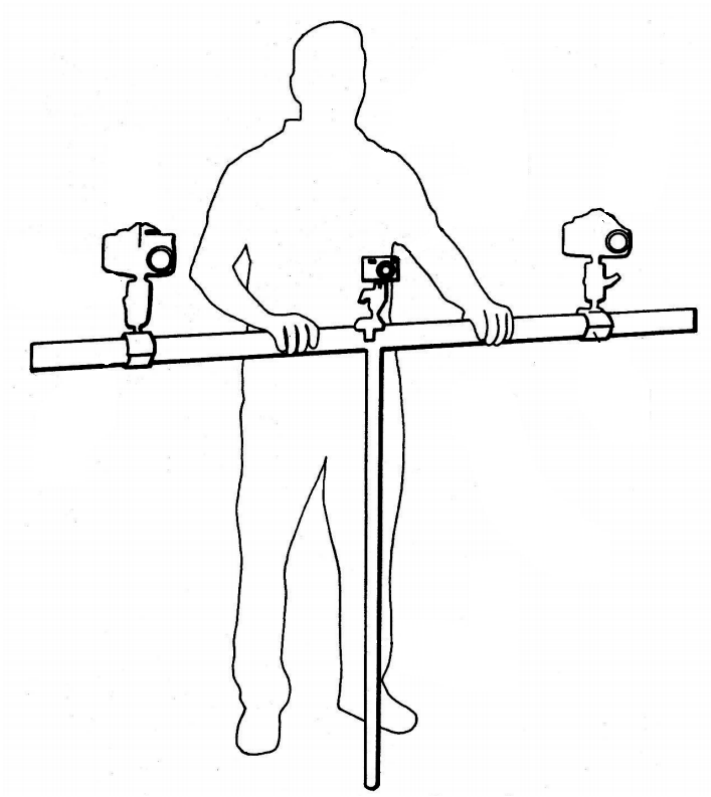

Figure 1. Photogrammetric equipment used in the present study.

To minimize the risks for operator and disturbance of the animals, the photographs were taken from different angles and perspectives in the animal's own habitat, from a distance of 10 to $15 \mathrm{~m}$, without altering the normal behavior or posture. For the subsequent morphometric analysis, photographs were transformed into three dimension files using software (PhotoModeller Scanner) that allows for the possibility of performing 20 body measurements as can be seen in Figure 2, following reviewed literature standards [33-35].

In addition, complementary phaneroptic variables were recorded. The profile and horns conformation, layer, pigmentation of mucous membranes and hooves were measured. Also, the development of the dewlap (very developed when the dewlap reaches the carpal joint and little developed when it ends in the sternum) and tail (very developed when the tail reaches the ground, little development when it reaches the hock) were recorded.

In addition, the following zoometric indexes have been calculated [34,36,37]:

- $\quad$ Cephalic index $=($ head width/head length $) \times 100$.

- Proportionality index $=$ (height at the withers/body length $) \times 100$.

- Relative depth of thorax index $=$ (back-sternal diameter/height at withers $) \times 100$.

- $\quad$ Posterior foot index $=($ height at hock/height at tail $) \times 100$.

- Relative thickness of cannon bone index $=$ (perimeter of the cannon/height at withers $) \times 100$.

- $\quad$ Saddling index $=($ height at withers + height at rump/2) - height at loins. 

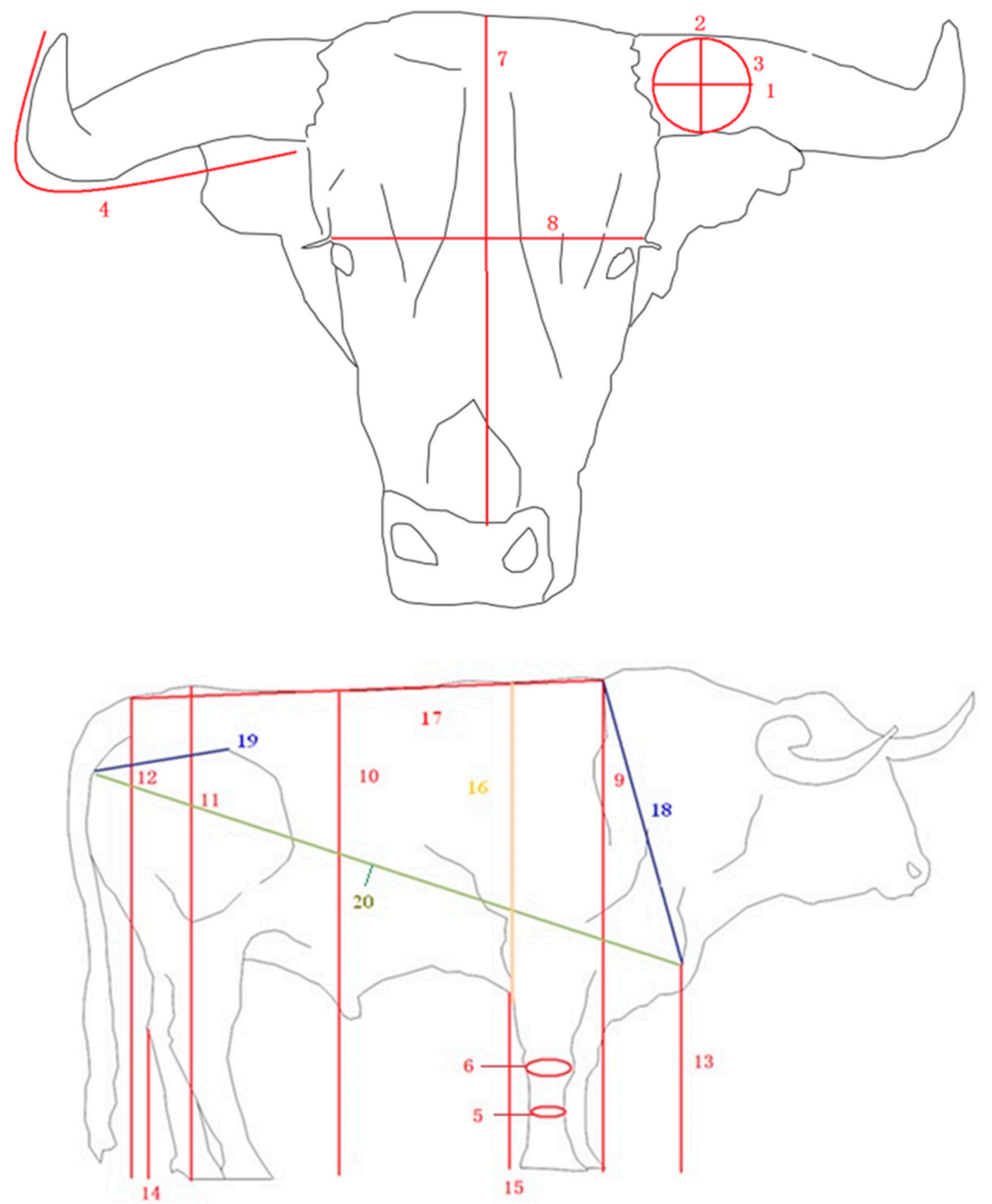

Figure 2. Graphical representation of the twenty body measures used in this study: horizontal diameter of the horn (1), horn perimeter (2), vertical diameter of the horn (3), exterior length of the horn (4), cannon perimeter (5), carpal perimeter (6), head length (7), head width (8), height at withers (9), height at loins (10), height at rump (11), height at tail (12), height at shoulder (13), hock height (14), sternum height (15), back-sternal diameter (16), back length (17), trunk length (18), rump length (19), and body length (20).

A descriptive statistical analysis of the variables was carried out, considering gender, for all the animals. Normality was verified using the Kolmogorov-Smirnov test. In turn, the data were subjected to a Student t-test for an independent samples test. Pearson correlation coefficients were estimated to analyze the relationships between the studied parameters. Chi-square tests $\left(\mathrm{X}^{2}\right)$ were used for the phaneroptic measurements determined. These statistical analyses were done with the SPSS ${ }^{\circledR}$ version 
19.0 package for Windows. Finally, a principal component analysis (PCA) was performed on the morphometrical data of the males selected by the breeders as representatives of the morphology of their genetic line (encaste). PCA was carried out using The Unscrambler (Camo Analytics AS. Oslo, Norway) version 11.0 software under the UEX Department of Animal Production and Food Science License. This software of chemometric origin in addition to develop models validate how the model will behave in the future in the face of new cases. The following variables were used in the PCA: exterior length of the horn, head length, head width, height at withers, height at loins, height at rump, height at tail, height at shoulder, hock height, back-sternal diameter, back length, trunk length, rump length and body length. The explained variance for principal components (PC) is expressed in \% and is calculated from the residual variance as:

$$
V \operatorname{Exp}(a)= \begin{cases}V \operatorname{Exp}(0)=0 \\ , \quad \\ & a=1 \ldots A \\ 0 & \text { if }(V \operatorname{Res}(a-1)-V \operatorname{Res}(a-1)-V \operatorname{Res}(a-1)-V \operatorname{Res}(a)) \leq 0\end{cases}
$$

where $V$ Res is any of the residual variance matrices listed in individual residual variance calculations and $V E x p$ is the corresponding explained variance matrix.

Accumulative explained variances for principal components (PC), also expressed as a percentage, are computed according to the following equation where VExp,cum is accumulative explained variances and $V$ Res is any of the residual variance matrices listed in Individual Residual Variance Calculations:

$$
V \operatorname{Exp}, \operatorname{cum}(a)=\frac{V \operatorname{Res}(0)-V \operatorname{Res}(a)}{V \operatorname{Res}(0)}
$$

\section{Results}

The twenty morphological parameters were first evaluated (Table 1), which included means, standard deviations, distributions, and Sexual dimorphism quotient SD (male/female). The exterior length of the horn was less variable in males than females (Table 1). In addition, compared to females, males had greater head width and length, horizontal and vertical diameter of the horn, back-sternal diameter, trunk, back, rump and body length, height at withers, loins, rump and height at tail. The dimorphism differences were corroborated numerically (Table 1); male body measurement/female body measurement $(\mathrm{m} / \mathrm{f})$ presented a global mean value of 1.1 , indicating bulls' morphology predominance over Lidia cows. 
Table 1. Average, maximum, minimum and standard deviation of studied morphological parameters and Student $\mathrm{t}$-test results between genders.

\begin{tabular}{|c|c|c|c|c|c|c|}
\hline Measures & Gender & Average & Maximum & Minimum & Standard Deviation & $\mathrm{SD}(\mathrm{m} / \mathrm{f})$ \\
\hline \multirow{2}{*}{ 1. Horizontal diameter of the horn } & M & $7.8^{\mathrm{a}}$ & 10 & 6 & 0.8 & \multirow{2}{*}{1.1} \\
\hline & $\mathrm{F}$ & $6.8^{\mathrm{b}}$ & 9.2 & 4.8 & 0.7 & \\
\hline \multirow{2}{*}{ 2. Horn perimeter } & M & $25.7^{\mathrm{a}}$ & 29.5 & 22 & 1.6 & \multirow{2}{*}{1.2} \\
\hline & $\mathrm{F}$ & $21.6^{\mathrm{b}}$ & 25.1 & 19.6 & 1.5 & \\
\hline \multirow{2}{*}{ 3. Vertical diameter of the horn } & M & $7.5^{\mathrm{a}}$ & 9.9 & 6.3 & 0.6 & \multirow{2}{*}{1.5} \\
\hline & $\mathrm{F}$ & $5.1^{\mathrm{b}}$ & 9 & 5.7 & 0.6 & \\
\hline \multirow{2}{*}{ 4. Exterior length of the horn } & $\mathrm{M}$ & $58.5^{\mathrm{a}}$ & 75 & 45 & 6.2 & \multirow{2}{*}{1} \\
\hline & F & $57.1^{\mathrm{b}}$ & 83.3 & 39.6 & 6.5 & \\
\hline \multirow{2}{*}{ 5. Cannon perimeter } & $\mathrm{M}$ & $19.7^{\mathrm{a}}$ & 25 & 16.8 & 1.3 & \multirow{2}{*}{1.2} \\
\hline & $\mathrm{F}$ & $16.3^{b}$ & 21.1 & 14.3 & 1.7 & \\
\hline \multirow{2}{*}{ 6. Carpal perimeter } & $\mathrm{M}$ & $31.4^{\mathrm{a}}$ & 35.5 & 21.5 & 1.8 & \multirow{2}{*}{1.2} \\
\hline & $F$ & $26.3^{b}$ & 30.6 & 20.1 & 1.8 & \\
\hline \multirow{2}{*}{ 7. Head length } & $\mathrm{M}$ & $49.1^{\mathrm{a}}$ & 59.2 & 43.3 & 3.4 & \multirow{2}{*}{1} \\
\hline & $\mathrm{F}$ & $47.1^{b}$ & 56.8 & 41.1 & 3.1 & \\
\hline \multirow{2}{*}{ 8. Head width } & $\mathrm{M}$ & $24.8^{\mathrm{a}}$ & 31 & 20.3 & 1.9 & \multirow{2}{*}{1.2} \\
\hline & $\mathrm{F}$ & $21^{\mathrm{b}}$ & 25.1 & 18.2 & 2.9 & \\
\hline \multirow{2}{*}{ 9. Height at withers } & $\mathrm{M}$ & $127.8^{\mathrm{a}}$ & 149.3 & 103.3 & 7.6 & \multirow{2}{*}{1.1} \\
\hline & $\mathrm{F}$ & $116.8^{\mathrm{b}}$ & 122.7 & 112.4 & 6.1 & \\
\hline \multirow{2}{*}{ 10. Height at loins } & M & $121.4^{\mathrm{a}}$ & 140.7 & 100.3 & 7.1 & \multirow{2}{*}{1.1} \\
\hline & $\mathrm{F}$ & $114.4^{b}$ & 118.7 & 111.2 & 5.0 & \\
\hline \multirow{2}{*}{ 11. Height at rump } & $\mathrm{M}$ & $124.6^{\mathrm{a}}$ & 147.2 & 105.3 & 6.4 & \multirow{2}{*}{1.1} \\
\hline & $\mathrm{F}$ & $117.6^{\mathrm{b}}$ & 122.7 & 112.5 & 5.7 & \\
\hline \multirow{2}{*}{ 12. Height at tail } & $\mathrm{M}$ & $124.3^{\mathrm{a}}$ & 147.4 & 104.3 & 6.3 & \multirow{2}{*}{1.1} \\
\hline & $\mathrm{F}$ & $115.9^{b}$ & 120.5 & 113.2 & 4.8 & \\
\hline \multirow{2}{*}{ 13. Height at shoulder } & $\mathrm{M}$ & $72.7^{\mathrm{a}}$ & 92 & 55.4 & 7.0 & 11 \\
\hline & $\mathrm{F}$ & $68.5^{b}$ & 70.2 & 65.9 & 5.5 & 1.1 \\
\hline 14. Hock height & $\mathrm{M}$ & 44.2 & 62.4 & 34 & 3.7 & 1 \\
\hline & $\mathrm{F}$ & 43.8 & 44.6 & 41.7 & 3.4 & 1 \\
\hline 15 Sternum height & $\mathrm{M}$ & 52.7 & 70.6 & 36.7 & 6.1 & 1 \\
\hline & $\mathrm{F}$ & 52.3 & 53.4 & 50.7 & 4.4 & 1 \\
\hline 16 Bakstornal diamotor & $\mathrm{M}$ & $74.5^{\mathrm{a}}$ & 97.4 & 58 & 7.6 & 12 \\
\hline 10. Dack-stemal diameter & $\mathrm{F}$ & $64.5^{\mathrm{b}}$ & 71.4 & 59 & 6.8 & 1.2 \\
\hline 17 Back lenoth & $\mathrm{M}$ & $116.9^{\mathrm{a}}$ & 144.1 & 99.5 & 7.4 & 11 \\
\hline 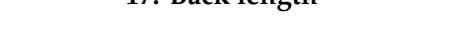 & $\mathrm{F}$ & $105.2^{b}$ & 111.4 & 101.9 & 8.7 & 1.1 \\
\hline 18 Trunk lonoth & M & $61.6^{\mathrm{a}}$ & 78.1 & 45.1 & 5.6 & 12 \\
\hline 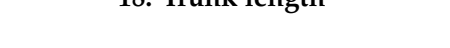 & F & $52.1^{\mathrm{b}}$ & 57.4 & 46.8 & 5.6 & 1.2 \\
\hline 19. Rumn lenoth & $\mathrm{M}$ & $48.8^{\mathrm{a}}$ & 60.7 & 37.4 & 4.4 & 11 \\
\hline 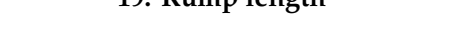 & $\mathrm{F}$ & $43.1^{b}$ & 46.5 & 39 & 4.5 & 1.1 \\
\hline 20 Body lenoth & $\mathrm{M}$ & $150.2^{\mathrm{a}}$ & 180.3 & 115.1 & 10.8 & 12 \\
\hline 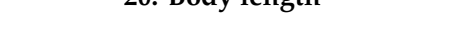 & $\mathrm{F}$ & $128.9^{b}$ & 133.2 & 125.3 & 9.5 & 1.2 \\
\hline
\end{tabular}

Different letters in the same column indicate significant differences $(p<0.05)$. Sexual dimorphism quotient SD (male/female). 
Table 2 showed the mean, standard deviation, and maximum/minimum values for the six morphometric indexes. Significant sexual dimorphism was observed in all the indexes. Lidia males were mesocephalic (50.6), while females were slightly dolicocephalic (44.6). The relative depth of the thorax index was significantly higher in the males as well as the relative thickness of cannon bone index. Posterior foot index and proportionality index were higher in the females. Finally, the males studied presented a marked degree of deviation of the thoracolumbar line compared with the Lidia cows, registering a saddling index of $4.8 \mathrm{~cm}$.

Table 2. Average, maximum, minimum and standard deviation of morphometric indexes studied and Student $\mathrm{t}$-test results between genders.

\begin{tabular}{|c|c|c|c|c|c|}
\hline Indexes & Gender & Average & Maximum & Minimum & Standard Deviation \\
\hline \multirow{2}{*}{ Cephalic index } & $\mathrm{M}$ & $50.6^{a}$ & 61.6 & 27.3 & 4.3 \\
\hline & $\mathrm{F}$ & $44.6^{b}$ & 58.1 & 26.8 & 6.2 \\
\hline \multirow{2}{*}{ Relative depth of torax index } & $\mathrm{M}$ & $59.5^{a}$ & 67.9 & 52 & 4.4 \\
\hline & $\mathrm{F}$ & $55.2^{b}$ & 65.8 & 47 & 4.1 \\
\hline \multirow{2}{*}{ Posterior foot index } & $\mathrm{M}$ & $35.4^{\mathrm{a}}$ & 51.8 & 27.3 & 2.6 \\
\hline & $\mathrm{F}$ & $37.8^{b}$ & 54.7 & 29.8 & 2.9 \\
\hline \multirow{2}{*}{ Proportionality index } & $\mathrm{M}$ & $85.4^{\mathrm{a}}$ & 104.1 & 74.7 & 4.6 \\
\hline & $\mathrm{F}$ & $90.6^{b}$ & 110.3 & 79.8 & 5.7 \\
\hline \multirow{2}{*}{ Relative thickness of cannon bone index } & $\mathrm{M}$ & $15.4^{\mathrm{a}}$ & 24.5 & 13.8 & 1.3 \\
\hline & $\mathrm{F}$ & $13.9^{\mathrm{b}}$ & 17.2 & 12.7 & 1.6 \\
\hline \multirow{2}{*}{ Sadding index } & $\mathrm{M}$ & $4.8^{\mathrm{a}}$ & 7.7 & 2.8 & 3.6 \\
\hline & $\mathrm{F}$ & $1.8^{\mathrm{b}}$ & 2.9 & 0.1 & 2.6 \\
\hline
\end{tabular}

Different letters in the same column indicate significant differences $p<0.05$.

Table 3 shows the linear correlations between the 20 variables analyzed in the males and females sampled. Horn morphometric variables were significant and positively correlated both in males and in females with higher values in the bulls. All the height variables were correlated, and the highest correlation value was obtained between height at rump and height at tail, 0.96 in males and 0.82 in females. Both genders presented a negative correlation between sternum height and back-sternal diameter (females -0.77 and males -0.73 ). Males had $59 \%$ of their parameters positively correlate, showing a harmonic morphostructural model. Females had slightly fewer harmonic features $(40 \%$ parameters correlated). 
Table 3. Pearson's correlation coefficients matrix among the 20 variables studied in males $(n=184, p<0.05$, presented in the inferior part of the table) and in females ( $n=80, p<0.05$, presented in the superior part of the table). Horizontal diameter of the horn (1), horn perimeter (2), vertical diameter of the horn (3), exterior length of the horn (4), cannon perimeter (5), carpal perimeter (6), head length (7), head width (8), height at withers (9), height at loins (10), height at rump (11), height at tail (12), height at shoulder (13), height at hock (14), sternum height (15), back-sternal diameter (16), back length (17), trunk length (18), rump length (19), and body length (20).

\begin{tabular}{|c|c|c|c|c|c|c|c|c|c|c|c|c|c|c|c|c|c|c|c|c|}
\hline Variable & 1 & 2 & 3 & 4 & 5 & 6 & 7 & 8 & 9 & 10 & 11 & 12 & 13 & 14 & 15 & 16 & 17 & 18 & 19 & 20 \\
\hline 1 & 1.00 & $0.39 *$ & $0.32 *$ & $0.28 *$ & 0.18 & 0.15 & 0.03 & $0.28 *$ & 0.18 & 0.15 & 0.11 & -0.09 & $0.35 *$ & 0.14 & 0.04 & 0.01 & 0.27 * & 0.11 & 0.17 & $0.23 *$ \\
\hline 2 & $0.66^{*}$ & 1.00 & 0.51 * & $0.20 *$ & -0.17 & 0.06 & 0.31 * & 0.09 & 0.19 & 0.19 & 0.18 & 0.15 & 0.10 & 0.21 * & 0.11 & 0.08 & 0.29 * & 0.08 & -0.12 & $0.26 *$ \\
\hline 3 & $0.73 *$ & $0.53 *$ & 1.00 & 0.41 & -0.03 & 0.15 & 0.13 & $0.25 *$ & 0.20 & 0.05 & 0.17 & 0.12 & $0.35 *$ & 0.08 & 0.13 & 0.26 * & $0.20 *$ & 0.10 & -0.18 & $0.33 *$ \\
\hline 4 & $0.52 *$ & $0.34 *$ & $0.33 *$ & 1.00 & 0.16 & -0.18 & $0.21 *$ & -0.04 & 0.03 & -0.12 & 0.01 & -0.18 & $0.41 *$ & -0.11 & -0.04 & 0.12 & 0.18 & -0.06 & 0.04 & $0.20 *$ \\
\hline 5 & 0.11 & 0.07 & 0.09 & 0.11 & 1.00 & -0.13 & -0.05 & 0,17 & 0.06 & -0.06 & 0.04 & 0.00 & 0.11 & 0.03 & 0.01 & -0.12 & -0.03 & 0.13 & -0.16 & 0.05 \\
\hline 6 & 0.19 & 0.07 & 0.15 & -0.13 & $0.53 *$ & 1.00 & 0.12 & 0.15 & 0.18 & 0.17 & 0.11 & $0.28 *$ & 0.13 & 0.15 & 0.13 & -0.04 & 0.15 & 0.20 * & 0.20 * & $0.21 *$ \\
\hline 7 & $0.41 *$ & $0.38 *$ & 0.25 * & 0.27 * & -0.02 & 0.14 & 1.00 & 0.34 * & 0.12 & 0.18 & 0.08 & 0.24 * & 0.09 & $0.35 *$ & $0.21 *$ & 0.18 & $0.28 *$ & 0.11 & 0.13 & $0.22 *$ \\
\hline 8 & $0.23 *$ & $0.25 *$ & 0.23 * & $0.20 *$ & -0.18 & 0.37 * & $0.53 *$ & 1.00 & 0.09 & 0.14 & 0.15 & 0.16 & 0.01 & $0.39 *$ & 0.27 * & 0.15 & 0.09 & 0.17 & $0.32 *$ & 0.07 \\
\hline 9 & $0.35 *$ & $0.40 *$ & 0.46 * & 0.13 & $0.25 *$ & $0.46 *$ & 0.48 * & $0.59 *$ & 1.00 & 0.58 * & $0.40 *$ & 0.57 * & 0.16 & 0.38 * & $0.20 *$ & $0.39 *$ & 0.19 & $0.21 *$ & 0.40 * & $0.33 *$ \\
\hline 10 & $0.25 *$ & $0.29 *$ & 0.28 * & -0.02 & 0.27 * & $0.41 *$ & $0.33 *$ & $0.53 *$ & $0.82 *$ & 1.00 & 0.38 * & 0.70 * & 0.19 & 0.27 * & 0.36 * & 0.41 * & $0.28 *$ & 0.29 * & 0.31 * & $0.38 *$ \\
\hline 11 & 0.31 * & 0.46 * & 0.38 * & 0.01 & 0.17 & $0.39 *$ & $0.41 *$ & 0.55 * & $0.72 *$ & 0.83 * & 1.00 & $0.82 *$ & 0.12 & 0.31 * & 0.41 * & 0.28 & 0.21 * & $0.33 *$ & $0.29 *$ & 0.51 * \\
\hline 13 & 0.17 & 0.00 & 0.19 & 0.15 & 0.02 & 0.04 & 0.05 & 0.29 * & 0.35 * & 0.32 * & 0.23 * & 0.31 * & 1.00 & -0.07 & 0.05 & 0.19 & -0.12 & $-0.25 *$ & 0.18 & 0.15 \\
\hline 14 & 0.11 & 0.12 & 0.18 & 0.09 & 0.12 & 0.35 * & 0.12 & 0.09 & 0.55 * & 0.49 * & $0.64 *$ & 0.78 * & -0.18 & 1.00 & $0.52 *$ & 0.17 & 0.19 & $0.22 *$ & 0.18 & $0.26 *$ \\
\hline 15 & 0.08 & $0.29 *$ & 0.18 & 0.16 & 0.03 & 0.07 & 0.02 & 0.12 & 0.59 * & 0.64 * & $0.52 *$ & 0.68 * & 0.38 * & 0.19 & 1.00 & $-0.77^{*}$ & 0.10 & 0.18 & 0.01 & 0.20 * \\
\hline 16 & 0.10 & 0.11 & 0.18 & 0.07 & -0.09 & 0.15 & 0.11 & 0.09 & $0.60 *$ & 0.48 * & 0.37 * & $0.53 *$ & 0.12 & 0.19 & $-0.73 *$ & 1.00 & 0.12 & $0.29 *$ & 0.18 & 0.18 \\
\hline 17 & $0.28 *$ & $0.32 *$ & 0.21 * & $0.22 *$ & 0.15 & 0.09 & $0.54 *$ & $0.25 *$ & $0.33 *$ & 0.54 * & $0.39 *$ & $0.61 *$ & -0.19 & $0.21 *$ & $0.28 *$ & 0.17 & 1.00 & 0.09 & 0.10 & $0.33 *$ \\
\hline 18 & 0.16 & 0.08 & 0.10 & -0.09 & 0.16 & 0.12 & 0.21 * & 0.10 & $0.52 *$ & 0.33 * & $0.48 *$ & 0.39 * & $-0.36 *$ & 0.51 * & 0.19 & $0.55 *$ & 0.09 & 1.00 & 0.58 * & 0.30 * \\
\hline 19 & 0.17 & -0.14 & 0.11 & $0.25 *$ & 0.07 & 0.21 * & 0.03 & 0.27 * & 0.35 * & 0.38 * & $0.40 *$ & 0.37 * & 0.11 & 0.31 * & 0.19 & 0.13 & $0.23 *$ & 0.25 * & 1.00 & $0.27 *$ \\
\hline 20 & 0.20 * & 0.09 & 0.31 * & 0.23 * & $0.22 *$ & 0.37 * & $0.32 *$ & 0.16 & 0.51 * & 0.43 * & 0.65 * & 0.49 * & 0.12 & 0.30 * & $0.23 *$ & 0.13 & 0.68 * & 0.26 * & 0.18 & 1.00 \\
\hline
\end{tabular}

* and bold indicates significant correlations $p<0.05$. 
Table 4 shows the percentage of different categories of morphological and phaneroptic variables studied and the results of the chi-square test depending on the gender. Studied males presented significantly less straight and more saddleback thoracolumbar lines than Lidia cows. Dewlap was little and developed in females and developed or very developed in males. Development of the tail was more evident in the males than in the females. No differences were observed between genders in coat and mucous membranes coloration (predominantly black), profile (mainly subconcave), and type of horns that were procerus (e.g., growth above the nape forward and curved in its medial and distal part, giving rise to crown forms and hook).

Table 4. Percentage of morphological and phaneroptic variables and chi-square test results of the animals studied depending on the gender.

\begin{tabular}{|c|c|c|c|c|}
\hline Variable & Category & $\%$ Male & $\%$ Female & $\mathbf{P}$ \\
\hline \multirow{5}{*}{ Profile } & Straight & 23.6 & 16.4 & \multirow{5}{*}{ n.s. } \\
\hline & Subconcave & 58.4 & 69.7 & \\
\hline & Concave & 0 & 0 & \\
\hline & Subconvex & 18 & 13.9 & \\
\hline & Convex & 0 & 0 & \\
\hline Horns & Proceros & 100 & 100 & n.s. \\
\hline \multirow{2}{*}{ Thoracolumbar line } & Straight & 16.1 & 51.4 & \multirow{2}{*}{ * } \\
\hline & Saddleback & 83.9 & 48.6 & \\
\hline \multirow{8}{*}{ Coat } & Black & 72.5 & 69.2 & \multirow{8}{*}{ n.s. } \\
\hline & Red & 7.7 & 8.4 & \\
\hline & Gray & 9.8 & 7.3 & \\
\hline & Brown & 5.5 & 6.6 & \\
\hline & Yellow & 0.9 & 1.5 & \\
\hline & Mixed & 3.1 & 5.2 & \\
\hline & White & 0.1 & 0.5 & \\
\hline & Others & 0.4 & 1.3 & \\
\hline \multirow{3}{*}{ Mucous membranes } & Black & 91.6 & 87.8 & \multirow{3}{*}{ n.s } \\
\hline & Pink & 7.8 & 10.1 & \\
\hline & Mixed & 0.6 & 2.1 & \\
\hline \multirow{3}{*}{ Hooves } & Black & 90.5 & 82.3 & \multirow{3}{*}{ n.s. } \\
\hline & Pink & 6.1 & 12.4 & \\
\hline & Mixed & 3.4 & 5.3 & \\
\hline \multirow{3}{*}{ Dewlap } & Little developed & $17.8 *$ & $48.2 *$ & \multirow{3}{*}{ * } \\
\hline & Developed & $56.2 *$ & $42.5 *$ & \\
\hline & Very developed & $26^{*}$ & $9.3 *$ & \\
\hline \multirow{3}{*}{ Tail } & Little developed & $10.1 *$ & $26.2 *$ & \multirow{3}{*}{ * } \\
\hline & Developed & $26.3 *$ & $67.7 *$ & \\
\hline & Very developed & $63.6^{*}$ & $6.1^{*}$ & \\
\hline
\end{tabular}

* indicates significant differences between genders $(n=264, p<0.05)$.

Finally, a principal component analysis has been made on 15 morphometric variables analyzed in males classified according to their genetic line. Variables that have no influence or weight were not included in the model. Males $(n=184)$ are represented spatially in Figure 3. Combining information presented in Table 5 and Figure 4, it could be observed that the PC1 (45\% of explained variance, Table 6) is determined mainly by the measurements of heights in the negative quadrant and the exterior length of the horn in the positive but with less influence. Two variables clearly conditioned PC2 (10\% of explained variance, Table 6)): sternum height and back-sternal diameter (Table 5 and Figure 4). 


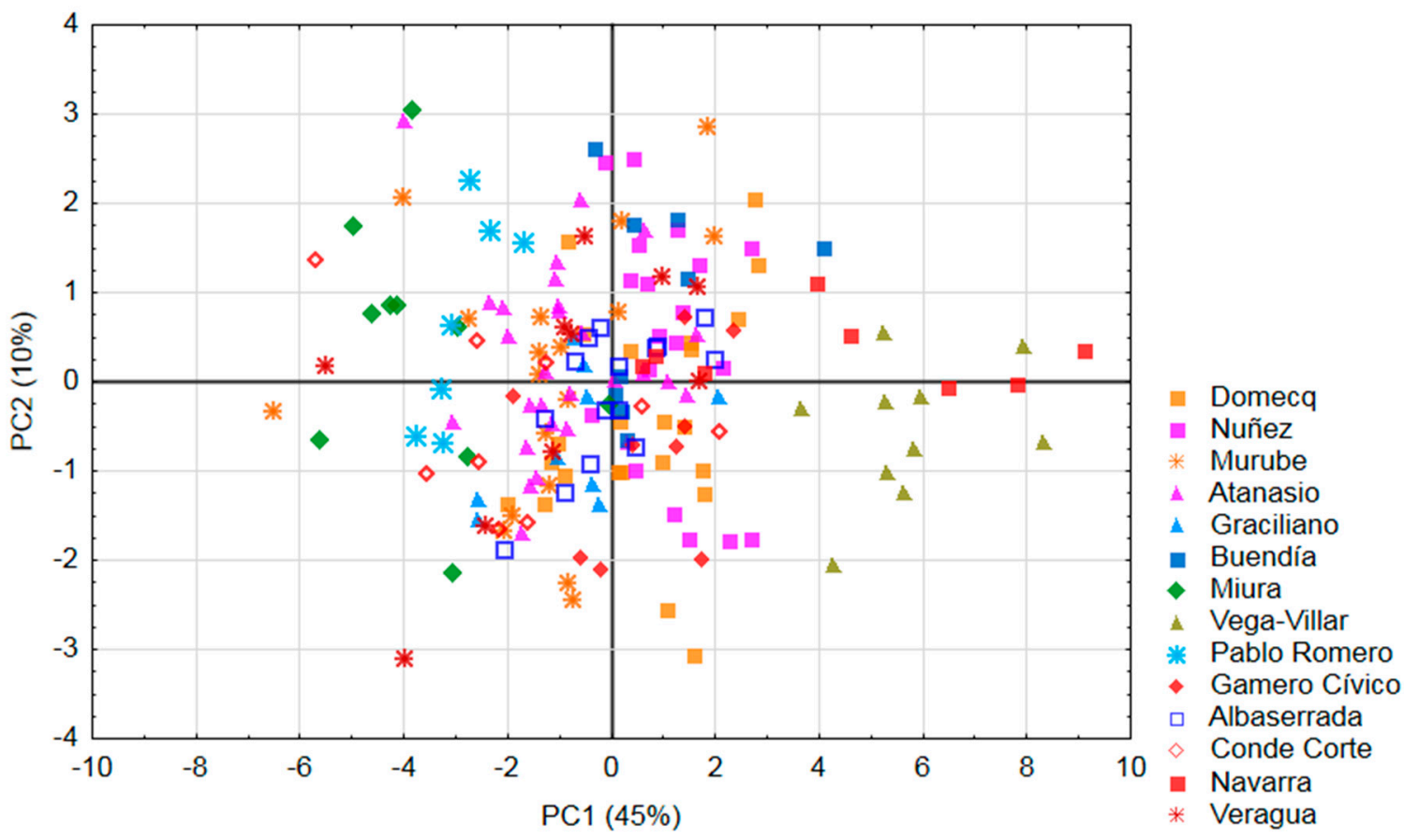

Figure 3. Principal component analysis on 15 morphometric variables analyzed in males $(n=184)$. Variables: Exterior length of the horn, head length, head width, height at withers, height at loins, height at rump, height at tail, height at shoulder, height at hock, sternum height, back-sternal diameter, back length, trunk length, rump length and body length.

Table 5. Principal component (PC) eigenvalues of the 15 morphological variables analyzed in males $(n=184)$.

\begin{tabular}{ccccccccccc}
\hline Morphological Variable & PC1 & PC2 & PC3 & PC4 & PC5 & PC6 & PC7 & PC8 & PC9 & PC10 \\
\hline Exterior length of the horn & 0.09 & -0.20 & 0.34 & -0.49 & 0.75 & -0.08 & 0.09 & -0.04 & 0.01 & -0.07 \\
Head length & -0.27 & -0.06 & 0.25 & 0.00 & -0.02 & 0.20 & -0.24 & 0.67 & 0.12 & 0.28 \\
Head width & -0.20 & 0.00 & 0.19 & -0.45 & -0.31 & -0.33 & -0.62 & -0.09 & 0.16 & -0.14 \\
Height at withers & -0.35 & -0.05 & 0.09 & 0.13 & 0.01 & -0.11 & 0.13 & 0.06 & 0.21 & -0.24 \\
Height at loins & -0.34 & 0.08 & 0.02 & -0.13 & -0.05 & 0.04 & 0.19 & -0.27 & 0.17 & 0.01 \\
Height at rump & -0.35 & 0.00 & -0.06 & -0.17 & -0.02 & 0.10 & 0.18 & -0.21 & 0.18 & 0.29 \\
Height at tail & -0.34 & 0.01 & -0.10 & -0.16 & -0.02 & 0.11 & 0.22 & -0.22 & 0.07 & 0.39 \\
Height at shoulder & -0.15 & 0.09 & 0.63 & 0.22 & -0.19 & -0.25 & 0.35 & -0.03 & -0.23 & -0.25 \\
Hock height & -0.19 & 0.01 & -0.38 & -0.47 & -0.14 & -0.17 & 0.31 & 0.41 & -0.49 & -0.18 \\
Sternum height & -0.15 & 0.72 & 0.03 & 0.01 & 0.16 & -0.10 & 0.04 & 0.10 & 0.18 & -0.12 \\
Back-sternal diameter & -0.23 & -0.63 & 0.06 & 0.13 & -0.12 & -0.03 & 0.10 & -0.01 & 0.07 & -0.14 \\
Back length & -0.24 & 0.08 & 0.10 & -0.05 & 0.02 & 0.61 & -0.30 & -0.29 & -0.50 & -0.29 \\
Trunk length & -0.25 & -0.08 & -0.45 & 0.21 & 0.28 & -0.13 & -0.15 & -0.03 & 0.23 & -0.47 \\
Rump length & -0.24 & -0.01 & -0.07 & 0.29 & 0.24 & -0.52 & -0.26 & -0.17 & -0.47 & 0.40 \\
Body length & -0.30 & 0.01 & 0.03 & 0.23 & 0.31 & 0.21 & -0.08 & 0.27 & -0.05 & 0.03 \\
\hline
\end{tabular}




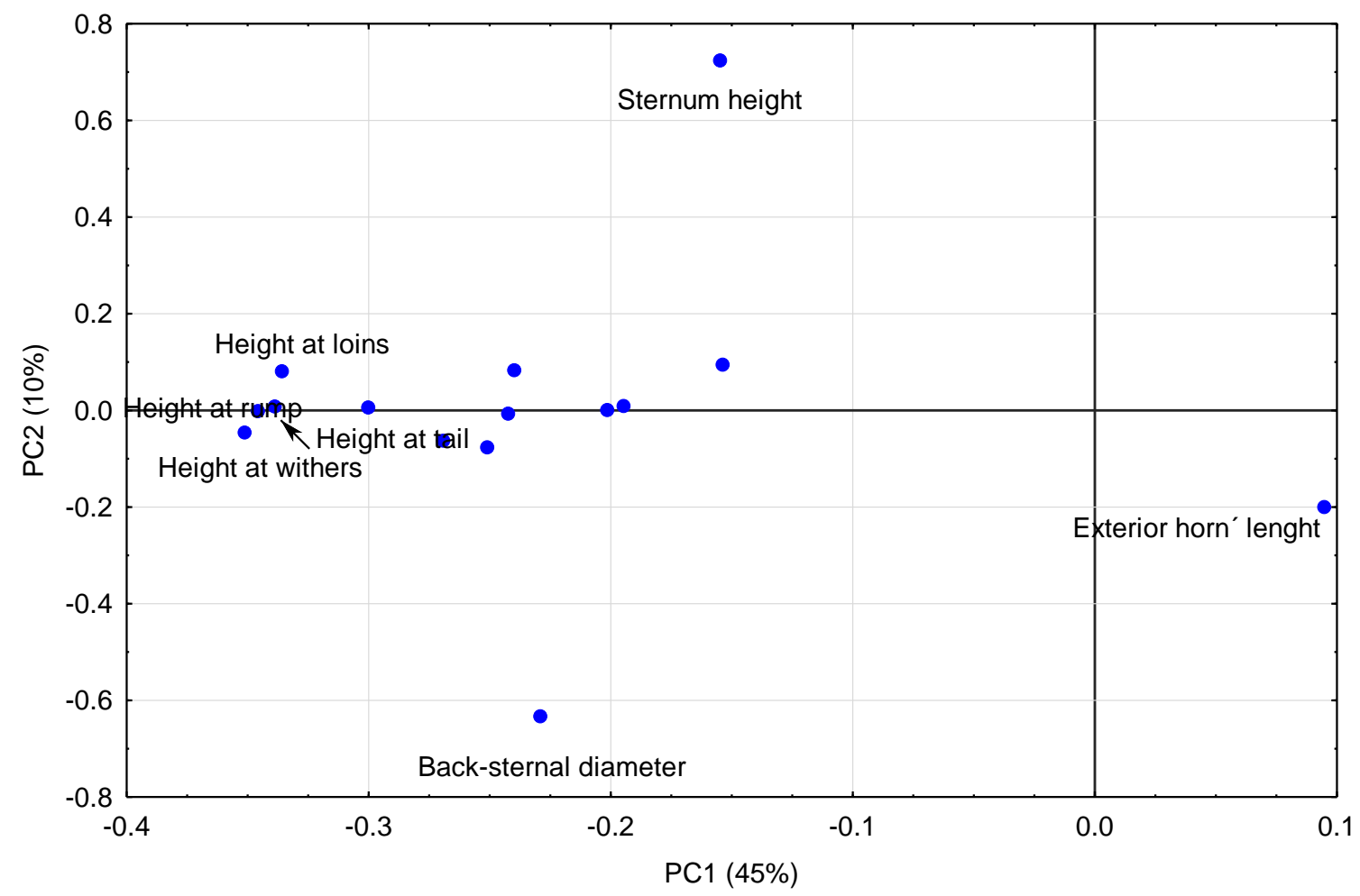

Figure 4. Distribution of the morphological variables for principal component 1 (PC1) and principal component 2 (PC2).

Table 6. Percentage of the explained and accumulated variance of the 10 principal components (PC) of the analyses.

\begin{tabular}{ccc}
\hline PC & Explained Variance & Accumulated Variance \\
\hline 1 & 45.4 & 45.4 \\
2 & 9.6 & 55 \\
3 & 8.9 & 63.9 \\
4 & 5.9 & 69.85 \\
5 & 5.8 & 75.68 \\
6 & 5.4 & 81.11 \\
7 & 4.7 & 85.82 \\
8 & 3.8 & 89.65 \\
9 & 3.6 & 93.23 \\
10 & 2.1 & 95.33 \\
\hline
\end{tabular}

\section{Discussion}

In general, the results obtained from body dimensions place the Lidia breed as mid-sized compared across the bovine species [34]. For the present study, significant parameter differences (Tables 1 and 2) corroborates the marked sexual dimorphism that exists in this breed [13]. There was clear evidence in the dimensions of the heights and body length, which indicate that the male is significantly larger than the female. In turn, significant differences among genders were observed in all indexes: cephalic, relative depth of the thorax and saddle higher in males and posterior foot and proportionality index higher in females, indicated different body proportions. The numerical estimation of dimorphism with an SD global mean value of 1.1 (Table 1) documented that the genetic selection pressure has been directed to the male morphology [38,39].

The mean height at withers observed in this study (Table 1) is less than previous means reported for Lidia bulls (136-143 cm) [17]. Compared with Spanish autochthonous breeds, the Lidia is framed in the group of mature, small-sized individuals, which includes the cachena $(122 \mathrm{~cm}$ male and $117 \mathrm{~cm}$ female) 
and the albera (126 cm male and $121 \mathrm{~cm}$ female) [1,40]. Mean Lidia height at withers values was smaller than the rest of Spanish autochthonous breeds [1,34]. Individuals from the Miura line presented the highest values and the ones from Vega-Villar and Navarra lines the lowest results (Figure 3) in accordance with reviewed literature $[13,41]$. These results may reflect the influence of farmers' preferences and the differences in the origin of the lines [5,6]. The sexual dimorphism of height-measurements was similar to that reported in other European cattle's breeds, which is approximately $10 \mathrm{~cm}$ differences [33].

The heights of the withers, loins, rump and tail were correlated within both males and females (Table 3). This work indicates that the Lidia bull's rump is slightly less than its withers ( $3 \mathrm{~cm}$ difference) giving a slightly "downhill" figure. On the contrary, female withers and rumps were level $(0.8 \mathrm{~cm}$ difference). Males also had a marked saddling back line, registering an index of $4.8 \mathrm{~cm}$. The saddling reported in the current study is similar to the previously published descriptions of this breed [13,37] and to the morphological prototype described for the rustic European bovine breeds [34]. The observed thoracolumbar line tended to be more saddled in the male $(83.9 \%)$ than in the female $(48.6 \%$; Table 4$)$.

In addition, a thorax significantly more developed was recorded in the male, endorsed in the measures of the back-sternal diameter and the length of the back, which generate significant differences between genders, $(74.9 \mathrm{~cm}$ in the male and $64.5 \mathrm{~cm}$ in the female). These results state that males were selected for heavy-muscled shoulders to have a more athletic, masculine appearance than females in accordance with some authors [41]. The idea that thoracic muscle and bone development is a selected character in the male was corroborated by the index of relative thorax depth $(59.5 \pm 8.1 \mathrm{~cm})$. All this, the results of genetic improvement, favors a great thoracic capacity that allows for greater oxygenation, leading to better performance of the bull during the taurine celebrations [5,13]. However, farmers selected males for variables of anterior third because the "badanudo" (developed dewlap) was a desired characteristic because it contributes to increase the visual predominance of this third. For the current study, a developed dewlap was presented in $56.2 \%$ of males, whereas in the females, $48.1 \%$ of the cases had less developed dewlaps (Table 4).

For the present study, the body length was also shorter than that reported for the main mature Spanish autochthonous breeds [1,42] but similar to that reported for the avileña, also Spanish native beef cattle breed [43]. Based on the variable trunk length, the Lidia breed could be framed in the group of medium cattle, although presenting great variations depending on the encastes (results of principal component analysis are shown in Figure 3) according to literature reviewed [12-16].

On the other hand, the index of proportionality gives us a value lower than 100 for males (85.4) and females (90.6), proving that females presented a poor beef conformation improved in the bulls specially in some genetic lines such as Pablo Romero that has been described closer to meat production prototype breeds, with a rectangular trunk [14]. Similar values have been reported for Uruguay breeds (88.2) and pirenaica breed (86.3) [44,45]. Moreover, the relative depth of the thorax index provided an idea of the sarcopoietic aptitude of each breed, considering a better beef conformation for a breed when it exceeds the more from 50 points. Average values of this index in Lidia individuals are close to 50 (Table 2) because farmers selected muscular development in this breed focusing on the athletic appearance and performance of charging behavior during the fight [46]. These characteristics are not desired among cattle raised solely for beef production.

The measures of height at shoulder and sternum provided information about the length of the animals' extremities, which, in this breed, are of a medium-low size in comparison with the rest of the bovine breeds, as a selection result because breeders have been selecting bulls with less height during the last century $[47,48]$.

The perimeter of the carpal region $(31.4 \mathrm{~cm}$ in males) was in accordance with data published by other authors in this breed $(31.2 \mathrm{~cm})$ [19] but smaller than that described for other cattle breeds $(33 \mathrm{~cm}$ for the retinta and $34 \mathrm{~cm}$ for the berrenda) [49]. The males' cannon perimeter $(19.7 \mathrm{~cm})$, were slightly higher to values published for this breed $[19,49](18.4 \mathrm{~cm})$ and considerably lower than values pointed out by other authors [17] $(21-24 \mathrm{~cm})$. On the other hand, this perimeter is lower than the reported 
for the pallaresa [50]; however, it is similar to that published for the cachena [40], both Spanish breeds. This indicates that the Lidia breed has a greater fineness compared to these Spanish native cattle.

The head conformation is often influenced by the origin area and environment and generally provides important characteristics of each breed [37,51]. The males in the current experiment had wider heads than the females, which generated a significantly higher cephalic index (Table 2). Head length was more variable in the males in the current study (43.3-59.2 cm in the male) than the same breed examined by Fuentes et al. [19] $(44.5-52 \mathrm{~cm})$ and by Barga-Besusán [17] $(45-53 \mathrm{~cm})$. Our results may have differed from the previous reports because we included a larger number of farms and genetic lines, which indicates that this breed may have greater morphological diversity than previously reported. Nevertheless, the means of head length obtained were lower than those described for some Spanish breeds $[50,52]$. The "shortened head" characteristic is often used when several authors described the Lidia breed $[17,53]$. With regard to males' width of the head $(20.3-31 \mathrm{~cm})$, values presented in this study exceed the range of measurement published $(21.5-28 \mathrm{~cm})$ [19] and were lower than others $(26-32 \mathrm{~cm})$ presented in literature reviewed for this breed [17] and native Spanish breeds [50,53]. The average cephalic index in Lidia bulls is 50.6 and 44.6 in cows, within values considered mesocephalic and slightly dolicocephalic, respectively [12,13].

All the cattle enrolled in this study presented proceros-type horns, in the form of a hook and with different proportions and directions in their trajectory $[54,55]$. The results on the variety of horn pigmentation, related to the coat, with the females being significantly thin and longer (Table 1), are in accordance with the literature consulted $[54,55]$. The mean horizontal diameter $(7.8 \mathrm{~cm})$ observed was slightly larger than the vertical one $(7.5 \mathrm{~cm})$ describing an elliptical section of the horn as pointed out by Aparicio-Sánchez [49], which suggests a horizontal flattening of the horn. Fuentes et al. [19] reported a slightly thicker horn $(8 \mathrm{~cm})$ that was practically circular. The horns' external length mean $(58.5 \mathrm{~cm})$ in the current project is considerably higher than that obtained by other authors thirty years ago [17], which was $46.7 \mathrm{~cm}$. There was likely increased selection for bulls with larger horns because the current results are in accordance with more recent published data [21,22,56].

Considering the phaneroptic variables studied (Table 4), both genders have similar characteristics, with the black coat being predominant in the breed, not so closely followed by the brown and gray, although the female tends to a greater variability of coatings and mucous membranes and hooves' pigmentation, as indicated by the bibliographic references consulted [13,41,54,57-61].

Generalized positive correlation between most of the parameters studied (Table 3), previously mentioned in results, supported that males of the fighting breed can be considered as representatives of a highly harmonic morphostructural model and the females of medium harmony according to consulted literature [62]. The differences between genders were probably due to increased selection pressure in the male as a result of the influence of the "trapio", that could be defined as a combination of physical qualities and presence necessary for the taurine celebrations, on the males' economic value $[55,57]$.

Finally, the "encastes" Núñez, Domecq, Gamero Cívico, Albaserrada and Santa Coloma (Graciliano and Buendia lines) with a common phylogenetic provenance (called "Vistahermosa") [63] were grouped in the central right part of Figure 3 in accordance with their similar morphological and genetic characteristics reported in literature reviewed $[6,13]$ because the bulls of these encastes presented mean values of heights and greater exterior length of the horns.

The similarities between Conde de la Corte and Atanasio-Lisardo that come from the same livestock line, called "Tamarón" [63] and historically sharing their breeding area (Salamanca, Spain [52]), placed them in the left quadrants of Figure 3, spread vertically by the greater influence of the sternum height on the Atanasio line individuals and back-sternal diameter on the Conde de la Corte ones. On the other hand, differences in the morphology of animals that come from genetically isolated herds $[5,6]$ such as the Miura and Pablo Romero lines (left above), with larger dimensions and individuals from Vega-villar (right below) and Navarra (right above) lines, could be clearly observed with a smaller size in 
Figure 3. The males of the "Veragua" line were dispersed in Figure 3 due to their lack of morphometric uniformity [13].

\section{Conclusions}

The adaptation of the photogrammetry to the Lidia breed allowed the first morphometric characterization obtaining a great variability in the parameters studied and values in accordance with the literature reviewed. The Lidia cattle breed presents smaller dimensions than other autochthonous Spanish breeds, with mostly a sub-concave mesocephalic profile. A considerable internal variability of the parameters studied has been observed, reflecting a marked sexual dimorphism and the existence of internal morphological differences between the genetic lines of the breed ("encastes"). A greater harmony in the male proportionality and body and muscle development compared to females could be explained by the fact that the pressure of morphological genetic selection has been exerted on the bulls due to their greater economic value.

Author Contributions: J.M.L.: Original draft; Image processing and statistics; Article writing. M.E.A.: Conducting the direction and management of the study; reviewing and editing. All authors have read and agreed to the published version of the manuscript.

Funding: This work has been partially funded by FEDER-INIA funds through the project RZ2008-00005-C02-01 entitled: "Genetic and morphological characterization of encastes of the lidia breed in danger in Castilla y León" (Spain).

Acknowledgments: We want to express our gratitude to Pedro Luis Rodríguez Medina, University of Extremadura, for performing the statistical analysis and for his wise advices and Lindsey Hulbert, Kansas State University, for her contribution to the improvement of this manuscript and her English review. We also want to acknowledge the anonymous reviewers that kindly improve the first draft.

Conflicts of Interest: Authors declare no conflict of interest.

\section{References}

1. MAPAMA (Ministerio de Agricultura y Pesca, Alimentación y Medio Ambiente). Sistema Nacional de Información de Razas (ARCA). Available online: https://www.mapa.gob.es/es/ganaderia/temas/zootecnia/ razas-ganaderas/razas/catalogo/autoctona-fomento/bovino/lidia/iframe-ejemplo-arca.aspx (accessed on 15 February 2020).

2. MECD (Ministerio de Educación, Cultura y Deporte). Subdirección General de Estadística y Estudios, Secretaría General Técnica, 2018. Estadística de asuntos taurinos 2012-2018 síntesis de resultados. Available online: http://www.culturaydeporte.gob.es/dam/jcr:5b65492f-a60a-4168-82a9-04fe9ee46205/estadistica-deasuntos-taurinos-2012-2018.pdf (accessed on 15 February 2020).

3. Cossío, J.M. Los Toros Tratado Técnico e Histórico, 1st ed.; Espasa Calpe: Madrid, Spain, 1967.

4. Vallejo, M. Anotaciones genéticas a la noción de casta en ganadería brava. Arch. Zootec. 1982, 31, $219-239$.

5. Cañón, J.; Fernández, J. El origen del Toro de Lidia y su relación con el toro actual. In Proceedings of the V Jornadas sobre ganado de Lidia, Pamplona, Spain, 25 November 2006; pp. 34-41.

6. Cañón, J.; Tupac-Yupanqui, I.; García-Atance, M.A.; Cortés, O.; García, D.; Fernández, J.; Dunners, S. Genetic variation within the Lidia bovine breed. Anim. Gen. 2008, 39, 439-445. [CrossRef]

7. Cañón, J. Mejora genética en el Ganado de Lidia: Métodos de Selección. In Manual de Reproducción y Genética del Toro de Lidia; ITACYL: Valladolid, Spain, 2008; pp. 40-46.

8. Alderson, L. The categorisation of types and breeds of cattle in Europe. Arch. Zootec. 1992, 41, 325-344.

9. Eding, J.H.; Laval, G. Measuring Genetic Uniqueness in Livestock. In Gene Banks and the Conservation of Farm Animal Genetic Resources, 3rd ed.; Institute of Animal Science and Health: Lysted, CA, USA, 2002; pp. 33-58.

10. Hintum, T.J.L. Drowing in the genepool: Managing genetic diversity in genebank collections. Ph.D. Thesis, Swedish University of Agricultural Sciences, Uppsala, Sweden, 1994.

11. Cruz-Sagredo, J. El toro de Lidia en la Biología, en la Zootecnia y en la Cultura, 1st ed.; Junta de Castilla y León, Consejería de Agricultura y Ganaderia: Valladolid, Spain, 1991; 230p.

12. Barga, R. El Toro de Lidia; Alianza Editorial: Madrid, Spain, 1995; 420p.

13. Rodríguez-Montesinos, A. Prototipos Raciales del Vacuno de Lidia; Ministerio de Agricultura, Pesca y Alimentación: Madrid, Spain, 2002; 272p. 
14. Calvo-Sáez, L.A. Escuela Gráfica de Toros; Junta de Castilla y León: Valladolid, Spain, 2005; 268p.

15. Navas, J.C. Bos Taurus; Ediciones los Sabios de Toreo: Madrid, Spain, 2006; 145p.

16. García-Llamazares, J.L. El Veterinario en los Espectáculos Taurinos; Colegio Oficial de Veterinarios de León: León, Spain, 2008; 210p.

17. Barga-Bensusán, R. El Toro de Lidia; Datos biométricos y Encuesta Estudio Sobre el Síndrome de las Caídas; Ediciones Sanidad y Seguridad Social: Madrid, Spain, 1980; 420p.

18. Sanes, M.; Meseguer, J.M.; Fuentes, F.C. Valoración de algunos parámetros zoométricos de posible interés en el toro de lidia. In Proceedings of the II Congreso Mundial Taurino de Veterinaria, Córdoba, Spain, 19 May 1997; pp. 245-249.

19. Fuentes, F.C.; Sánchez, J.M.; Sánes, M.; Meseguer, J.M.; Gonzalo, C. Caractérisation de certains paramétres biométriques chez le taureau de combat. Rev. Méd. Vét. 2001,152,157-164.

20. Martín, R. Estudio anatómico y biométrico de la cornamenta del toro de Lidia. Med. Vet. 1984, 1, 545-553.

21. Fuente, D.; Gómez, J.P.; Guerra, J.; Morales, J.; Carpintero, M.; Duran, J.M.; Fernández, J.; Flores, B.; Hebrero, C.; Moreno, F.; et al. Estudio estadístico de los cuernos de toros lidiados durante las temporadas de 1998 y 1999 en la plaza de toros de las Ventas en función del encaste de procedencia e importancia de la lupa binocular en el análisis de los mismos. In Proceedings of the IV Symposium Nacional del Toro de Lidia, Zafra, Spain, 30 October 1999; pp. 249-253.

22. Ezpeleta, E. Biometría de los cuernos de las reses de Lidia. In Proceedings of the IV Symposium Nacional del Toro de Lidia, Zafra, Spain, 30 October 1999; pp. 227-325.

23. Herrera, M. Metodología de caracterización zooetnológica. In La Ganadería Andaluza en el Siglo XXI, Patrimonio Ganadero Andaluz; Consejería de Agricultura y Pesca, Junta de Andalucía: Sevilla, Spain, 2007; pp. 435-448.

24. Negretti, P.; Bianconi, G. Morphological survey through computerised image analysis. In Proceedings of the 7th World Conference on Brown Swiss Cattle Breeders, Verona, Italy, 3-7 March 2004; pp. 195-201.

25. Negretti, P.; Bianconi, G.; Bartocci, S.; Terramoccia, S.; Verna, M. Determination of live weight and body condition score in lactating Mediterranean buffalo by Visual Image Analysis. Livest. Sci. 2008, 113, 1-7. [CrossRef]

26. Schrader, A.M.; Ferreira, S.M.; VanAarde, R.J. Digitalphotogram-metry and laser range finder techniques to measure African elephants. S. Afr. J. Wildl. Res. 2006, 36, 1-7.

27. Keith, M.; Bester, M.N.; Bartlett, P.A.; Baker, D. Killer whales (Orcinus orca) at Marion Island, Southern Ocean. Afr. Zool. 2001, 36, 163-175. [CrossRef]

28. Proffitt, K.; Garrott, R.; Rotella, J.; Lele, S. Using form analysistechniques to improve photogrammetric mass-estimation methods. Mar. Mamm. Sci. 2008, 24, 147-158. [CrossRef]

29. Wu, J.; Tillett, R.; Mcfarlane, N.; Ju, X.; Siebert, J.P.; Schofield, P. Extracting the three-dimensional shape of livepigs using stereo photogrammetry. Comput. Electron. Agric. 2004, 44, 203-222. [CrossRef]

30. De la Peña, A.; Pérez, L.M.; González, F.; Arana, P. Utilización de técnicas fotogramétricas para el estudio de la morfología del caballo. Arch. Zootec. 2006, 55, 309-312.

31. Tasdemir, S.; Yakar, M.; Urkmez, A.; Inal, S. Determination of body measurements of a cow by image analysis. In Proceedings of the International Conference on Computer Systems, CompSysTech'08, Gabrovo, Bulgaria, 12-13 June 2008; pp. 81-87.

32. Gaudioso, V.R.; Sanz-Ablanedo, E.; Lomillos, J.M.; Alonso, M.E.; Javares-Morillo, L.; Rodríguez, P. "Photozoometer": A new photogrammetric system for obtaining morphometric measurements of elusive animals. Livest. Sci. 2014, 165, 147-156. [CrossRef]

33. Dervillé, M.; Patin, S.; Avon, L. Races bovines de France, 1st ed.; France Agricole: Paris, France, 2009; 288p.

34. Sañudo, C. Atlas Mundial de Etnología Zootécnica, 1st ed.; Editorial Servet: Villatuerta, España, 2011; 818p.

35. Gomez, M.D.; Azor, P.J.; Alonso, M.E.; Jordana, J.; Valera, M. Morphological and genetic characterization of Spanish heavy horse breeds: Implications for their conservation. Livest. Sci. 2012, 144, 57-66. [CrossRef]

36. Salako, A.E. Application of Morphological Indices in the Assessment of Type and Function in Sheep. Int. J. Morphol. 2006, 24, 13-18. [CrossRef]

37. Alderson, J.L.H. The development of a system of linear measurements to provide an assessment of type and function of beef cattle. Anim. Genet. Res. 1999, 25, 45-55. [CrossRef]

38. Lomillos, J.M.; Alonso, M.E.; Gaudioso, V.R. Análisis de la evolución del manejo en las explotaciones del toro de lidia. Desafíos del sector. ITEA 2013, 109, 49-68. 
39. Lomillos, J.M.; Alonso, M.E. The Lidia Breed: Management and Medicine. In Animal Reproduction in Veterinary Medicine; IntechOpen: London, UK, 2020; pp. 1-22.

40. Sánchez García, L.; Iglesias, A.; Fernández, A.; Viana, J.L.; Vallejo, M. Morena Gallega cattle breeds with limited numbers: Origin, productive characteristics and conservation programmes. Anim. Genet. Resour. Inf. 1997, 21, 23-33. [CrossRef]

41. Sotillo, F.; Ramirez, A.R.; Sotillo, J.L. Producciones equinas y de ganado de Lidia. Biotipología del toro. In Zootecnia. Bases de Producción Animal; Buxadé, C., Ed.; Mundiprensa: Madrid, Spain, 1996; pp. $233-246$.

42. Jordana, J.; Pelegrin, M.; Piedrafita, J. Relaciones genéticas en bovinos españoles obtenidas a partir del estudio de caracteres morfológicos. ITEA 2001, 87, 50-64.

43. Albertí, P.; Panea, B.; Sañudo, C.; Olleta, J.L.; Ripoll, G.; Ertbjerg, P.; Christensen, M.; Gigli, S.; Failla, S.; Concetti, S.; et al. Live weight, body size and carcass characteristics of young bulls of fifteen European breeds. Livest. Sci. 2008, 114, 19-30. [CrossRef]

44. Rodríguez, M.; Fernández, G.; Silveira, C.; Delgado, J.V. Estudio ético de los bovinos criollos del Uruguay. I. Análisis biométrico. Arch. Zootec. 2001, 39, 43-47.

45. Parés-Casanova, P.M.; Jordana, J. Zoometric measurements of cephalic conformation in adult bovine males and females (Bos taurus). Vet. Zootech-Lith. 2008, 43, 65-73.

46. Alonso, M.E.; Sánchez, J.M.; Robles, R.; Zarza, A.M.; Gaudioso, V.R. Relation entre la fréquence de la chute et différents paramètres hematologiques chez le toreau de combat. Rev. Med. Vet. 1997, 148, 999-1004.

47. Domecq Solís, B. Lidia del Toro en la Plaza. La Ficha del Ganadero. In Del Toreo a la Bravura, 1st ed.; Alianza Editorial: Madrid, Spain, 2008; pp. 418-421.

48. Prieto, J.L. Valoración Morfológica en el Toro de Lidia. In Valoración Morfológica de Los Animales Domésticos; Ministerio de Medio Ambiente y Medio Rural y Marino: Madrid, Spain, 2009; pp. 309-364.

49. Aparicio-Sánchez, G. Exterior de los Grandes Animales Domésticos; Imprenta Moderna: Córdoba, Spain, 1960; 324p.

50. Parés-Casanova, P.M.; Sinfreu, I.; Villalba, D. Application of varimax rotated principal component analysisin quantifying some zoometrical traits of a relict cow. Korean J. Vet. Res. 2013, 53, 7-10. [CrossRef]

51. Fernández, J. Evolución de las Explotaciones Ganaderas. In Un Siglo de Toros 1905-2005, 1st ed.; Unión de Criadores de Toros de Lidia: Madrid, Spain, 2005; pp. 102-118.

52. Miró, F.; Vivo, F.; García, J.; Díaz, A.; López, J. Determinación de algunos parámetros cefálicos del vacuno de raza Retinta. Arch. Zootec. 1988, 137, 75-86.

53. Sanchez-Belda, A. Geografía Española del Toro de Lidia, 1st ed.; Ministerio de Agricultura: Madrid, Spain, 1980; 86p.

54. Rodríguez-Montesinos, A. Pelajes y Encornaduras del Toro de Lidia; Consejo General de Colegios Veterinarios de España: Madrid, Spain, 1994; 310p.

55. Alonso, M.E.; Lomillos, J.M.; González, J.R. La Cornamenta del Toro de Lidia Análisis de Su Integridad y Efecto del Enfundado; EOLAS Ediciones: León, Spain, 2016; 168p.

56. Fuente, D.; Guerra, J.; Herrero, C.; Morales, J. Estudio del crecimiento de las astas de las reses lidiadas en la plaza de toros de las ventas durante las temporadas taurinas 1995-1996. In Proceedings of the III Symposium Nacional del Toro de Lidia, Zafra, Spain, 25 October 1997; pp. 139-144.

57. Pérez-Santos, C. Características Morfológicas Externas del Toro de Lidia, 2nd ed.; Sate-Aritza: Barcelona, Spain, $2001 ; 128$ p.

58. Ferret, D. Bases Anatomiques et Physiologiques de la Selection et du Comportement du Taureau de Combat; These Doctorel. École Nationale Veterinaire d'Alfort: Alfort, France, 2005.

59. Prieto Garrido, J.L.; Del Pino, J. Guía De Campo Del Toro De Lidia Pintas, Particularidades y Encornaduras; Almuzara: Córdoba, Spain, 2013; 192p.

60. Prieto Garrido, J.L. El Toro Bravo en el Campo; Almuzara: Córdoba, Spain, 2014; 400p.

61. Prieto Garrido, J.L. El Toro Bravo. Ganaderías Míticas; Almuzara: Córdoba, Spain, 2012; 582p.

62. Herrera, M. Un Método Para la Valoración del Modelo Morfoestructural en las Razas Caninas. In Proceedings of the Primer Encuentro de Docentes e Investigadores Zooetnólogos Españoles, Córdoba, Spain, 21-22 February 2001.

63. Mira, F. Hierros y Encastes del Toro de Lidia; Guadalquivir Ediciones: Sevilla, Spain, 1998; 682p.

(C) 2020 by the authors. Licensee MDPI, Basel, Switzerland. This article is an open access article distributed under the terms and conditions of the Creative Commons Attribution (CC BY) license (http://creativecommons.org/licenses/by/4.0/). 